\title{
Evidential markers derived from visual perception in Spanish dialects: a contrastive study of por lo visto and se ve (que)
}

\begin{abstract}
It is well known that verbs of perception (PV) frequently give rise to discursive uses. As such, PVs are used for example as evidential markers through grammaticalization processes. The present study focuses on two evidential markers of Spanish derived from the visual PVs ver ('to see'), namely, por lo visto and se ve (que). Although the attention dedicated to these evidential markers in Spanish has increased considerably in recent years, there is still a lack of contrastive studies that take into account the dialectal variation of this phenomenon. The present study aspires to take a first step in filling this gap by contrastively studying por lo visto and se $v e$ (que) in different dialects of Spanish by means of a comprehensive, empirical study.

The results display the distribution of por lo visto and se ve (que) in the dialectal map of Spanish. In addition to the diatopic variation, the frequency differences also reveal some significant diaphasic variation (in this case linked to discursive genre). In general, the results show that se ve (que) is used more frequently and appears more often in informal registers than por lo visto. Likewise, se ve (que) turns out to be more widespread geographically than por lo visto.
\end{abstract}

\section{Keywords}

Evidential markers, verbs of perception por lo visto, se ve que, dialectal variation, registers, discursive corpora

\section{Introduction ${ }^{1}$}

Over the past few decades, verbs of perception (PVs) have received considerable attention in the linguistic bibliography (cf. for instance Enghels 2007; Hanegreefs 2008; IbarretxeAntuñano 1999; Vesterinen 2010). The attraction towards the study of this verbal category should not be surprising, since the act of perception constitutes the fundamental bridge between the external reality and our human knowledge of that reality (Cuenca \& Marín 2000) and, more specifically, verbs expressing perception are the most tangible evidence of the direct interaction between physical perception and its linguistic codification (Fernández Jaén 2012: 155). Moreover, the large majority of the bibliography dedicated to PVs tend to focus on verbs of visual perception (such as English to see, to look), which reflects the fact that vision is a dominant perception modality that acts as a primary source of objective information (Viberg 1984: 136; Sweetser 1990: 38), clearly illustrated by expressions such as 'seeing is believing'.

From a linguistic point of view, then, a consequence of this cognitive superiority is that verbs of visual perception are also more frequent within this verbal category and they tend to occur in a wide range of semantic and syntactic contexts. This semantic-syntactic complexity results in a complex polysemous profile with extensions that go beyond the lexical field of perception and even attain the discourse level. Indeed, it is well known that PVs frequently give rise to

\footnotetext{
${ }^{1}$ This work was supported by the Spanish Ministry of Economy and Competitiveness, MINECO (Project FFI201675249-P, La atenuación pragmática en su variación genérica: géneros discursivos escritos y orales en el español de España y América).
} 
discursive uses through grammaticalization processes. For example, the use of the imperative forms mira, look, guarda, kijk as discourse markers (DM) has been studied in a wide range of languages and from different perspectives (cf. among many others Pons Bordería 1998, Cuenca \& Marín 2000, Van Olmen 2010; González Melón \& Hanegreefs 2011; Tanghe \& Jansegers 2014).

The present study focuses on two discursive uses derived from the visual PV ver ('to see') in Spanish, namely the evidential markers por lo visto and se ve (que) ('apparently'). Whereas the former, por lo visto, is generally recognized as a discursive particle in the scholarly literature (Ruiz Gurillo 2005, González Ramos 2016, Kotwica 2016, Cornillie \& Gras 2015, Albelda 2016, to appear, Izquierdo 2016), and appears in different dictionaries of discourse particles (for example Briz et al. online, Santos Río 2003, Fuentes 2009), the status of se ve (que) as an evidential marker is less straightforward: it is not included in the above cited dictionaries and has hardly been studied (with the exception of Cornillie \& Gras 2015, Albelda 2016, to appear). However, Albelda (2016, to appear) recently argued that se ve (que) is a quasi-grammaticalized construction that bears the specific characteristics attributed to discursive particles in Briz (www.dpde.es, Introduction, online). It can appear in two formal variants: (i) in initial position of a discursive member (se ve que), integrated in the utterance; and (ii) in medial or final position of the discursive member (se ve), with parenthetic character.

The following examples illustrate the use of both evidential markers in different genres, registers and dialects:

(1) Enc: (platícame del teatro infantil) Inf.- Bueno, mira, yo recuerdo que hice teatro infantil casi como una casualidad. Una productora porque necesitaba una niñita muy chiquitita fue al teatro infantil. Había niños chicos, que a lo mejor ahí conseguía una niña que necesitaba y pues me vieron que estaba yo allí corriendo entre los pasillos, me metía entre los decorados, y pues, por lo visto, esa era la niña que ellos necesitaban para su personaje. Hablaron con mi mamá, mi mamá aceptó (...).

(Macrocorpus de la Norma Culta. Entrevista 4, Ciudad de México)

(2) P: el niño se abrazó a su madre $\uparrow /$ acercó a la cara asíî/ así// y no la desapegó

C: (LAUGHING) ¡ay qué bo- ay!/ ¡qué bonito! (...)

P: y hacía así con los ojitos $\uparrow$ (gesture)// pero claro/ él no veía $\rightarrow \mathbf{s e}$ ve $\downarrow$ bien a su madre/ y se apegó a su madre/ y luego el ayudante del cirujano nos decía/ allí dentro os hacía así aaaa (gesture) que lo sacaran fuera

(Val.Es.Co. corpus 2002, G.68.B1: 146-155)

Both por lo visto and se ve express source of information. In example (1) the source is inferential: The speaker makes an inference based on what she experienced during her presence at the children's theater. In (2), speaker P narrates the behavior of a child during a surgical procedure. In this spontaneous conversation, P disrupts the sequence 'verb + complements' and inserts the parenthetical construction se ve. The independence of the construction is evidenced by the fact that it is surrounded by pauses and displays falling intonation. Se ve is in medial position within the utterance, and it has propositional scope, i.e. scope over the entire proposition él no veía bien a su madre.

Despite the growing interest in these Spanish evidential markers in recent years, up to the present, no contrastive study has yet been conducted on the dialectal variation of this phenomenon. However, a first intuitive approach to corpus data suggests that there are some significant differences, not only along the dialectal axis of variation, but also taking into account diaphasic variation. Hence the main objective of this study, which is to present the first 
contrastive corpus-based study of the evidential markers por lo visto and se ve (que), by focusing both on the dialectal and the diaphasic differences. Within this general objective, some fundamental, more specific research questions arise:

1. Do we indeed observe dialectal differences in terms of frequency of use of both markers? Are there any areas where one specific form dominates? And in that case, what could be the underlying explanation for these diverging dialectal patterns?

2. Are there any diaphasic differences in the use of both markers? That is to say, do we observe any differences according to register (formal vs. informal speech)?

3. From a qualitative point of view, we know that both markers are defined as evidentials as far as they express the source of information. However, the question arises as to what extent their evidential meaning differ according to the mode of knowledge expressed (reportative, inferential, visual).

In order to address these questions, an extensive empirical study was conducted on a total of more than 40 corpora from colloquial conversations and semi-formal interviews representing different dialectal areas of Spanish (see Section 4).

The outline of this paper is as follows: Section 2 describes the general notion of evidentiality in Spanish, before situating the discourse particles under study within this larger domain of evidentiality (Section 3). Section 4 outlines the methodology adopted throughout the study, by explaining both the parameters of analysis and the corpus compilation. Section 5 provides the results of the contrastive analysis, in terms of (1) dialectal variation (Section 5.1), (2) diaphasic variation (Section 5.2) and (3) differences according to the mode of knowledge expressed (Section 5.3). Finally, Section 6 presents the conclusion and some further perspectives.

\section{The notion of evidentiality in Spanish}

From a typological perspective, Spanish is considered a non-evidential language (see for example the World Atlas of Languages Structures Online ${ }^{2}$, and also a.o. Diewald \& Smirnova 2010 (eds.), Albelda 2015 (ed.) González Ruiz et al. 2016 (eds.) or Cornillie \& Izquierdo (eds. 2018). Unlike many Amerindian languages in contact with Spanish (Quechua, Aymara, and Amazonian languages, or in Mexico, Chinantec, Mixtec, as well as some Uto-Aztecan and Mayan languages; Aikhenvald, 2004: 291) that do require the obligatory expression of some evidential category, Spanish lacks obligatory evidential morphemes in the grammar system. However, Spanish does have "evidential strategies" (in the sense of Aikhenvald 2004). As Albelda (2016: 237) specifies, in general, these are polyfunctional linguistic forms capable of expressing different values, one of them being evidential. For example, a different value is attributed to the verb aparecer in each of the following sentences (examples taken from Albelda 2016: 238):

(3) Ricardo parece un astronauta con ese abrigo.

Ricardo looks like an astronaut with that coat

Whereas in example (3) parecer establishes a mere relation of similarity between Ricardo and an astronaut, the assertion in (4), instead, results from a process of inference from the part of

${ }^{2}$ http://wals.info/feature/78A\#2/16.6/149.8 (last seen 06/02/2018). 
the speaker based on some specific indications observed. That is, only the case of (2) can be considered evidential according to the definition of evidentiality proposed by Aikhenvald (2004: 3), namely, a grammatical category that identifies the source of information on which the assertion is based.

Examples like (2) illustrate that Spanish, in spite of not being an evidential language in the strict sense, has been developing certain evidential mechanisms over time. In order to account for this expression of evidentiality in languages that typologically are considered not evidential, several authors have argued in favor of a semantic-functional definition of evidentiality (a.o. Chafe \& Nichols 1986; Biber \& Finegan 1988, Boye 2010, Diewald \& Smirnova 2010, Hassler 2010). According to this broad definition, evidentiality is considered a semantic domain that expresses the source of information through various linguistic mechanisms that go beyond the purely morphological level. Indeed, Spanish has at its disposal various mechanisms, forms and polyfunctional constructions to indicate the source of information. The root of these mechanisms lies, for example, in perception verbs like ver, parecer (Fernández Jaén 2012, Albelda 2016, Cornillie 2016), some uses of the synthetic future or the imperfect (Bermúdez 2005, Escandell 2010), certain generalizing constructions with se or tú (Hugo 2011), the rise of clitics (Bermúdez 2005), certain values of modal verbs as deber (Schwenter 1999, De Saeger 2006, Cornillie 2016), as well as certain prosodic patterns (Estellés 2015).

Some of these evidential forms in present-day Spanish have even acquired a primary evidential meaning today, through processes of grammaticalization or constructionalization. This is the case, for example, for the discursive particles al parecer, dizque (in HispanoAmerican dialects), and the particles under study, namely por lo visto and se ve (que) (Miglio 2010, González Condom 2015; Kotwica 2015; De la Mora \& Maldonado 2015; Albelda 2016; González Ramos 2016; Torner 2016).

For this study, we thus take as a starting point a broad cognitive-functional perspective on evidentiality (Cornillie 2016, Boye 2010, Hassler 2010, De la Mora \& Maldonado 2015, Kotwica 2015, Albelda 2016), which views evidentiality as a semantic domain that expresses the source of information through various linguistic mechanisms and confers a fundamental importance to the role of context. The cognitive-functional approach is based on the premise that language does not constitute a cognitive capacity separate from other human faculties, but is closely related to other cognitive processes. Therefore, linguistic structures reflect the structure of other cognitive domains of the human being.

According to this functionalist perspective, and together with the semantic condition of expressing the source of information, other criteria have been established to recognize evidential values. In general, it is accepted that evidentiality is a deictic category (Frawley 1992, Bermúdez 2005, Whitt 2010, Hassler 2010), that is, the purpose of the evidential mechanism is to mark the relation between the speaker and the action s/he is describing. According to Boye (2010), it is also considered that evidentiality must have propositional scope, that is, evidential elements act on propositions (not on states of affairs or speech acts) and, therefore, they do not contribute to the truth conditions of the utterances.

As we will see throughout the corpus study (Section 5), these last two criteria turn out to be especially useful for the analysis of se ve (que), which is in the process of constructionalization, since they allow us to discriminate between the uses that meet the criteria to be considered as an evidential marker and those uses that do not. For example, in a sentence like (2) above, one of the arguments in favor of an evidential reading of se ve is that it has scope over the entire 
proposition: "él no veía bien a su madre". On the contrary, in an example such as "se ve [un castillo en el cuadro]" se ve doesn't have propositional scope, but rather acts upon a state of affairs.

\section{Evidentiality of por lo visto and se ve (que)}

As has been explained above (See Section 1), PVs referring to visual and auditory perception modalities tend to foster discursive uses (a.o. Hanegreefs 2008, Fernández Jaén 2012, Tanghe \& Jansegers 2014). Anderson (1986: 276) states that very often, they give rise to evidential markers through processes of grammaticalization. This is also the case for the two evidential particles under study in the present paper. However, there seem to be some important differences between both particles related to their degree of fixation and subsequent status of evidential marker.

First por lo visto seems to present a higher degree of grammaticalization or - more recently constructionalization than se ve (que). ${ }^{3}$ Indeed, the sequence por $+l o+v i s t o$, based on the combination of the prepositional phrase with the participle form of ver, has developed historically towards a fixed grammatical expression of evidentiality characterized by its syntactic independence, positional mobility, parenthetical character and propositional scope:

(4) A- ¿Qué era buena la familia?

B- Lo que dicen es que se ha peleado con el novio; por lo visto... porque la consideran, pues yo la veo una familia muy bonica

(Habla culta de Granada, Encuesta XVI, p. 274)

However, in addition to these fixed uses, there are still compositional uses of por lo visto, as exemplified in the following example taken from the Diccionario de partículas del español, (Ruiz Gurillo, online):

(5) Dudar de su triunfo parece una temeridad por lo visto hasta ahora.

(ABC Electrónico, España, CREA, 1997)

As Ruiz Gurillo points out, in this example por lo visto is not a particle, but a mere adjunct. In these cases, it does not appear between commas, it usually stands behind the verb and visto retains its original, ocular meaning. Something similar happens with other variants of this combination, which are also free, and therefore, do not fulfill one of the basic features to be considered as a particle, namely its fixation: por lo visto y oído, por lo visto y escuchado, a juzgar por lo visto, por lo que se ha visto, etc. (Kotwica, 2017). As a consequence, these noncompositional uses have been discarded from the present study.

\footnotetext{
${ }^{3}$ The concept of constructionalization has been used in different ways. In this article we follow the proposal of Traugott \& Trousdale (2013). In general, constructionalization (Cxzn) and grammaticalization (Gzn) are two tightly intertwined theoretical approaches. However, the first one seems to display some advantages for the study of discourse particles: while the processes of Gzn tend to focus either on form or on meaning, Cxzn attributes the same weight to both form and meaning, and therefore its evolution is seen iconically in the form-meaning pair. Also, Cxzn works with a broad notion of meaning, which includes function; that is, it refers not only to the lexical base of an expression but also to its pragmatic features and possibilities. For a further discussion of the advantages of Cxzn over Gzn, see Jansegers \& Gries (2017).
} 
Compared to por lo visto, the degree of fixation in se ve (que) is much lower. Apart from its fixed use as an evidential marker, the sequence se ve (que) can express a wide range of combinations with compositional value, and therefore, it is essential to delimit these contexts from the evidential value. Albelda (2016) presents an exhaustive overview of the possible combinatory possibilities ranging from more free combinations, with a straightforward compositional value (e.g. the Direct Physical Perception senses, in example 6 below), towards more fixed and grammaticalized uses, such as the evidential one (example 7).

(6) vivimos en el sexto/ desde la cocina se ve la calle saludó

(Corpus Val.Es.Co 2002, ML.84.A.1- Líneas 864-865)

(7) P: Y AHORA TE MANDAN si quieres $\uparrow /$ chorizo de allí/ yy queso de allí/ y eso lo mandan allí/ hay algunos que se dedican $\downarrow$ se ve $\downarrow$ a exportar// y venden en los bares

(Corpus Val.Es.Co 2002, PG119.A1- Líneas 241-242)

In (7) the oral discourse is interrupted by se ve, which constitutes a phonic group on its own and acts as a parenthetical, presenting thus evidential value. In example (6), on the contrary, la calle constitutes the Direct Object of the transitive verb ver and se ve refers to a direct physical perception and thus preserves its original, compositional meaning of visual perception.

Both grammaticalized evidential markers in Spanish express an indirect mode of knowledge. That is, contrary to a direct mode of knowledge, where the information is acquired immediately through physical perception via the external senses (vision, hearing, smell), the information expressed by evidential markers in Spanish is acquired in an indirect way, that is, mediated through processes of inference or reportativity. As a consequence, they have been characterized as indirect evidentials, either with inferential or reportative uses (Kotwica 2016, Albelda 2016, to appear, Cornillie 2016, González Ramos 2016, Marcos 2016). ${ }^{4}$

\section{Data and method}

For the retrieval and annotation of the corpus data, the present paper adopts the following threestep procedure:

(i) The retrieval of all instances of the sequences por lo visto and se ve (que) from a wide variety of corpora.

In order to study the distribution of these two particles in Spanish, a large dataset was compiled incorporating the majority of corpora available to date (and to the best of our knowledge) covering colloquial conversations and semi-formal interviews and encompassing various geographical areas.

The total number of words analyzed is around 7 million, distributed in the following way:

\footnotetext{
${ }^{4}$ More recently, however, some authors have been questioning the reportative value of the evidential markers in Spanish (cf. Izquierdo 2016 and Estellés in press). They suggest that these reportative uses are essentially inferences generated on the basis of oral, reported data.
} 


\begin{tabular}{|c|c|c|c|}
\hline & Corpus & City / Country & Nr. of words \\
\hline \multirow{26}{*}{ 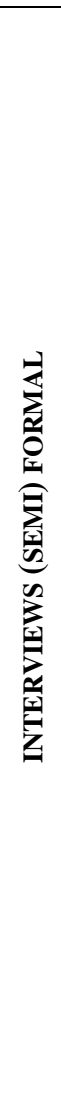 } & \multirow[t]{12}{*}{$\mathrm{MCNCH}$} & Madrid & 40000 \\
\hline & & Sevilla & 40000 \\
\hline & & Santiago de Chile & 58000 \\
\hline & & San Juan de Puerto Rico & 55000 \\
\hline & & San José de Costa Rica & 67000 \\
\hline & & Lima & 65000 \\
\hline & & Las Palmas de Gran Canaria & 69000 \\
\hline & & La Paz & 65000 \\
\hline & & Caracas & 63000 \\
\hline & & Buenos Aires & 56000 \\
\hline & & Bogotá & 55000 \\
\hline & & México & 63000 \\
\hline & \multirow[t]{8}{*}{ PRESEEA } & Valencia & 420000 \\
\hline & & Alcalá & 160000 \\
\hline & & Castellón & 575000 \\
\hline & & Málaga & 160000 \\
\hline & & Medellín & 435774 \\
\hline & & Montevideo & 497172 \\
\hline & & Santiago de Chile & 792000 \\
\hline & & Caracas & 177000 \\
\hline & \multirow[t]{2}{*}{ EGREHA } & San José de Costa Rica & 29000 \\
\hline & & Guatemala & 10000 \\
\hline & Eslora & Galicia & 410000 \\
\hline & Habla culta de Granada & Granada & 168000 \\
\hline & Entrevistas 1985-1986 & Monterrey & 855000 \\
\hline & Total interviews & & 5384946 \\
\hline \multirow{17}{*}{ 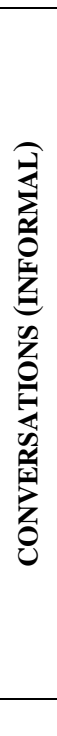 } & COGILA & Granada & 36000 \\
\hline & Val.Es.Co. (2002) & Valencia & 100000 \\
\hline & Val.Es.Co (2.0) & Valencia & 250000 \\
\hline & \multirow[t]{2}{*}{ COLAm } & Buenos Aires & 100000 \\
\hline & & Santiago de Chile & 100000 \\
\hline & \multirow[t]{7}{*}{ AMERESCO } & Tucumán & 14000 \\
\hline & & Monterrey & 107000 \\
\hline & & Barranquilla & 68000 \\
\hline & & La Habana & 75000 \\
\hline & & Iquique & 427000 \\
\hline & & Madrid & 360000 \\
\hline & & Ciudad de México & 23000 \\
\hline & COJEM & Palma de Mallorca & 120000 \\
\hline & Colloquial conver & Sevilla & 14000 \\
\hline & Acapulco Shore Conversations & Acapulco & 28000 \\
\hline & Total conversations & & 1449000 \\
\hline & TOTAL CORPUS & & 6833946 \\
\hline
\end{tabular}

Table 1. Corpus compilation and total number of words

It has to be noted that in the retrieved corpora, there is a nearly perfect coincidence between the selected genre and register: the interviews cover formal and semiformal registers, whereas the conversations corpora represent informal speech. Therefore, in the present study genre and register are assimilated. However, from Table 1 it is clear that the total corpus is characterized by a marked quantitative disproportion and certain heterogeneity concerning both the genre/register variation and the geographical variation. As to the former, the total number of words in the semiformal and formal register studied is 5384 946, whereas the total number in 
the informal register is only 1449000 words. Likewise, the sample size per city/country also greatly varies from one area to another. These quantitative differences are of course due to the availability of corpora in the linguistic market today. Nevertheless, it is an undeniable warning sign for the representativeness of the results: it is clear that for some areas with a larger number of samples, such as the Valencian or Andalusian area of Spain, the results may be considered more conclusive than for cases such as Guatemala, for which we only have a small sample of the EGREHA corpus.

From these corpora, all the instances of the sequences se ve (que) and por lo visto were retrieved; in the case of por lo visto different transcriptions were taken into account such as for example the aspiration of the implosive consonants: $p o(h)$ lo vi(h)to. The outcome of this datagathering method leads to a total number of 816 occurrences retrieved, 90 of por lo visto and 726 of se ve (que).

\section{(ii) The second step consists in the analysis and annotation of all these occurrences and the elimination of those cases that are not evidentials.}

Given that the object of study only involves the sequences por lo visto and se ve (que) used as evidential markers, all occurrences retrieved in step (i) had to be manually inspected and annotated for the variable [+/- evidential]. Only the evidential instances were preserved, all the others were eliminated from the corpus.

More precisely, for the sequence por lo visto, and according to what was mentioned in Section 3), some combinations with other phrases were not taken into account (por lo visto y oído etc.), as well as the formal variants with inflection of the verb (por lo que hemos visto, por lo que se ha visto, etc).

In the case of se ve (que) the decision for inclusion or exclusion of the forms is somewhat trickier. As commented above (Section 3), se ve (que) is a sequence with a highly polysemous profile, displaying a semantic continuum going from more compositional uses expressing direct physical perception through more indirect perception and abstract meanings such as cognitive or evaluative perception, towards even more abstract grammaticalized/constructionalized uses. As a consequence, in order to assess the evidential value of the sequence, its level of fixation and subsequent constructionalization was taken into account. More precisely, in order to determine the evidential value of se ve (que), the following criteria were considered:

1) For the formal variant se ve que, occurrences where the sequence is syntactically free and semantically compositional, were excluded. This occurs in two contexts, namely expressing: (a) concrete physical, visual perception (example 8) and (b) abstract cognitive/evaluative perception (Fernández Jaén 2012: 350, cf. example 9). Whereas examples of se ve que under (a) could be considered uses of visual evidentiality (indirect physical perception) (see below, step iii), it has to be kept in mind that in these cases, se ve que is not an evidential particle, precisely for maintaining its compositional, physical perception sense. Examples under (b) have not been considered as evidentials because they don't express source of information but rather a kind of subjective valorization from the part of the speaker.

(8) Luego en el ordenador se ve que tienes hora y media de comida 
(9) Es algo que se ve que está súper divertido/ el ambiente está padrepus

(corpus Ameresco Monterrey)

2) Regarding the formal variant se ve (without que), only the parenthetical uses of the sequence as illustrated above (example 7) were included in the frequency counts. On the contrary, all the instances where se ve is integrated syntactically and phonically in the phrase were excluded. This occurs in three types of combinations, namely (a) se ve + DO (cf. example 6 above); (b) se ve + predicative complement of the $\mathrm{DO}+\mathrm{DO}$ (se ve bueno el chaleco, 'the vest looks good'); (c) pronominal use of se ve in the pseudocopular construction (NGLE 2009, §38.5) (la presidenta se ve presionada por el pueblo, 'the president is pressured by the people').

After the exclusion of these cases, a total number of 306 occurrences of both evidentials were maintained, 90 of por lo visto and 216 of se ve (que).

(iii) In the third step, all the remaining occurrences were annotated for the mode of knowledge expressed.

The scientific literature dedicated to the study of evidentiality attempts to characterize and classify evidentials in different categories and establish different criteria that justify such classification. One of the most widespread categories is the MODE OF KNOWLEDGE, that is, the type of process through which the information has been acquired. In general, a distinction is made between direct vs. indirect evidence: the former is based on a sensory physical perception (mostly visual or auditory), while the latter is based on inferential or reportative sources. As already mentioned above (Section 3 and references therein), according to previous studies, evidential forms in Spanish can only express indirect modes of knowledge, where the information is not acquired firsthand, but in an indirect way and mediated through processes of inference or reportativity.

On the one hand, inferential evidentiality implies that the information is obtained through a process of a reasoning (inference) from the part of the speaker, which can be based on sensory data, general knowledge of the world, or no sensory evidence at all, and therefore, fully conjectural. Depending on each of these possibilities, Squartini (2008) distinguishes between circumstantial, generic or conjectural inferences. On the other hand, reportative evidentiality indicates that the information is acquired through testimony of other people or institutions (media, government sources, etc.).

In order to determine the mode of knowledge of all evidential occurrences, some formal and semantic tests proposed by Albelda (in press) have been applied, such as for example the cooccurrence with dicendi verbs for the case of the reportative evidentiality. This is illustrated in example (10), where it is the presence of "lo que dicen" that favors an analysis in terms of reportative evidentiality:

(10) A: nos habían avisado que esas casas/ se nos ceden (..j.)

C: y entonces nos han dicho que ya las quiereen/ por lo vistoo// derruir porquee ...

(Corpus PRESEEA-A.68 Alcalá)

In other cases, the evidential marker co-occurs with expressions of doubt or ignorance, such as no sé, no lo sé, yo qué sé ('I do not know') or with conditional and future verb tenses, which favor an analysis in terms of inferential evidentiality. In example (11) speaker J indicates that 
s/he doesn't know (no lo sé) what s/he has previously affirmed through se ve que, which points to a low degree of certainty in what $\mathrm{s} / \mathrm{he}$ is saying, and therefore implies an inference:

(11) J: por cierto $\uparrow$ la Miriam esa (...) se ha quedado más tapón/ tío

A: ¡coño!/ es que ella es bajita

$\mathrm{J}: \mathrm{ya} / \mathrm{no} \downarrow$ es que sus padres se ve que son bajitos/ no lo sé

(Corpus Valesco 2.0, Conversación 14, Intervenciones 66-70)

Finally, as explained with respect to example 8 above, the corpus analysis of the sequence se ve que yields a small number of cases that express visual evidentiality. Another example is (12), where the speaker refers to a phenomenon that he saw with his eyes, and therefore, expresses physical perception, although it is a generalization and not some concrete and specific event.

(12) I: bueno/ eeh/ eso es digamos un fenómeno que está pasando (...) en este barrio La Castellana/ y es que seestán tumbando las casas viejas grandes/ y las están transformando en edificios/ entonces cada vez/ se ve que tumban una casa nueva/ van remplazándola por edificios

(Corpus PRESEEA Medellín. Entrevista M23_001)

In the remainder of this paper, we will discuss the results of the corpus analysis with the objective of answering the three main research questions.

\section{Results and discussion}

The extraction of all the occurrences of evidential por lo visto and se ve que left us with 306 examples in total, 90 of which are instances of por lo visto and 216 of which are cases of se ve (que). According to these numbers, it is clear that se ve (que) is used most frequently, a fact which is confirmed (indeed, emphasized) when we count the occurrences per 100000 words:

- por lo visto: $1.31 / 100000$

- se ve (que): $3.16 / 100000$

In general terms, the relative frequencies in the corpus thus clearly indicate that use of se ve (que) is much more frequent than por lo visto: it is used more than twice as much.

However, looking at the concrete cases in more detail, it catches the eye that the distribution of these two markers is not homogeneous at all among the entire corpus. More precisely, there are some remarkable differences according to the dialectal variant (5.1), the register (5.2) and the modes of knowledge (5.3). Each of these axes of variation will be discussed in more detail in the next sections.

\subsection{Dialectal differences}

\subsubsection{Por lo visto}

From the 90 occurrences of por lo visto retrieved from the corpus, 79 are from Spain $(87,8 \%)$ and only 11 from Latin America (12,2\%). We thus immediately see that the use of por lo visto seems to be highly characteristic of European Spanish.

Indeed, of the 17 American cities under study, por lo visto is only registered in 5 cities: Lima (3,08/100000 words), Mexico City (1,16/100000 words), Santiago de Chile (1,00/100000 
words), Caracas (0.83/100000 words) and Buenos Aires (0,64/100000 words). On the contrary, it appears in every Spanish city in the corpus, as summarized in the following table:

\begin{tabular}{|l|l|l|}
\hline Dialectal variant & Cases/total words & Nr./100000 words \\
\hline Granada & $31 / 204000$ & 15,20 \\
\hline Málaga & $15 / 160000$ & 9,38 \\
\hline Sevilla & $5 / 54000$ & 9,23 \\
\hline Las Palmas de Gran Canaria & $4 / 69000$ & 5,80 \\
\hline Alcalá & $9 / 160000$ & 5,63 \\
\hline Madrid & $2 / 40000$ & 5,00 \\
\hline Valencia & $7 / 770000$ & 0,91 \\
\hline Palma de Mallorca & $1 / 120000$ & 0,83 \\
\hline Castellón & $3 / 575000$ & 0,52 \\
\hline Galicia & $2 / 410000$ & 0,49 \\
\hline \multicolumn{2}{|l|}{ Table 2. Frequencies of por lo visto in Spain } \\
\hline
\end{tabular}

Looking at this table in more detail, it is striking that some of the areas with more frequent use of this evidential marker are situated in the extreme south of the Iberian peninsula, in Andalusia (Granada, Seville and Malaga). Visualizing this distribution of por lo visto on a map of Spain, Figure 2 illustrates that it occurs in all the cities analyzed, but with a striking concentration in the Andalusian area.

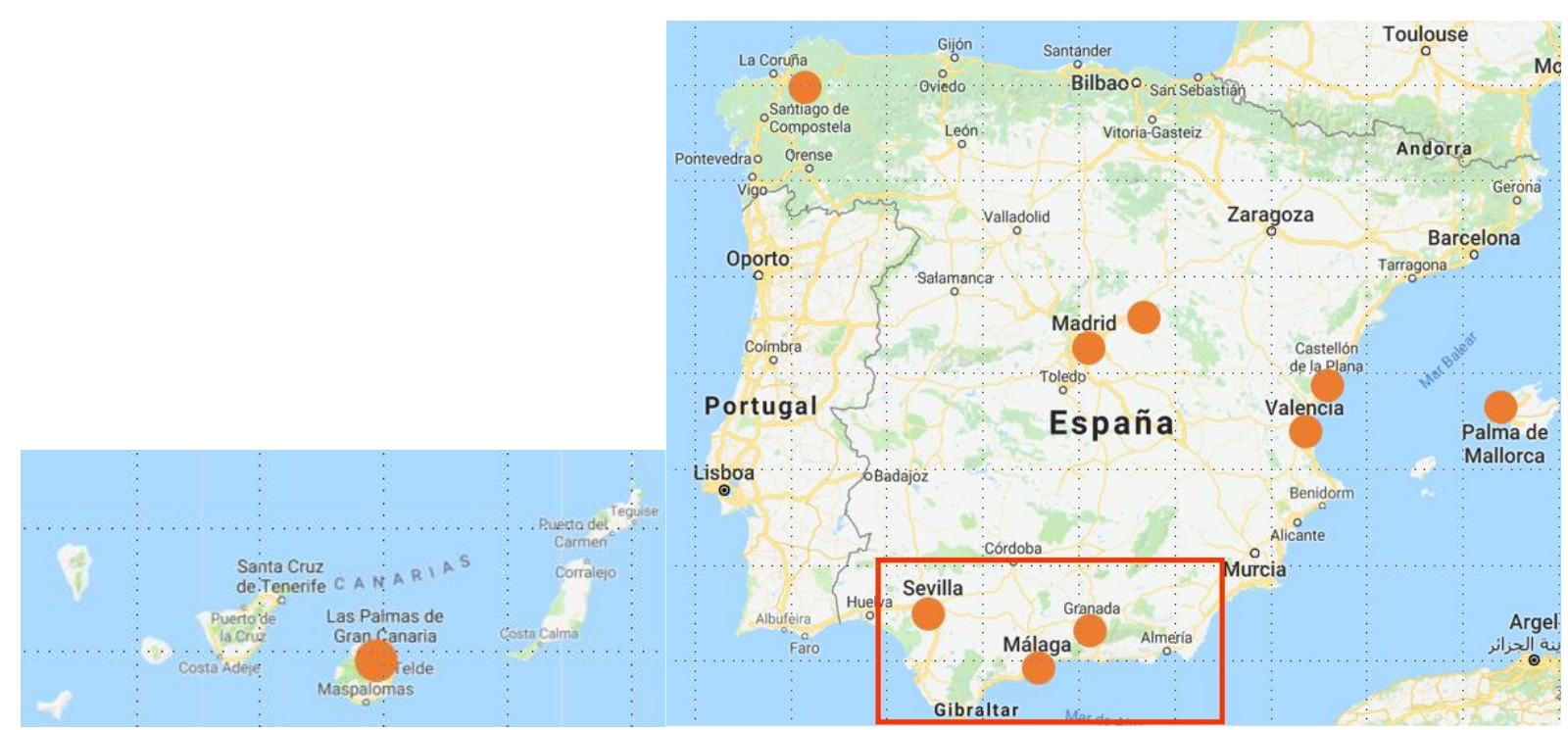

Figure 1. Concentration of por lo visto in the Iberian peninsula (map: Google maps)

In sum, the differences according to the dialectal variant of por lo visto point thus to a use of por lo visto that is less frequent in Latin America than in Spain, and within Spain, there seems to be a concentration in the Andalusian area.

\subsubsection{Se ve (que)}

The data obtained for se ve (que) show a somewhat different picture. To begin with, the general frequencies already indicate that se ve (que) seems to be more equally distributed than por lo visto: from the 218 occurrences of se ve (que) retrieved, 157 are from Spain (72\%) and 61 are situated in Latin America (28\%). 
The table below lists all the American cities where se ve (que) was attested:

\begin{tabular}{|l|l|l|}
\hline Dialectal variant & Cases/total words & Nr./100000 words \\
\hline Acapulco & $2 / 28000$ & 7,10 \\
\hline Caracas & $11 / 240000$ & 4,60 \\
\hline Montevideo & $16 / 497172$ & 3,22 \\
\hline Mexico City & $2 / 63000$ & 3,17 \\
\hline La Paz & $2 / 65000$ & 3,08 \\
\hline La Habana & $2 / 75000$ & 2,67 \\
\hline Puerto Rico & $1 / 55000$ & 1,82 \\
\hline Monterrey & $7 / 855000$ & 1,66 \\
\hline Lima & $1 / 65000$ & 1,54 \\
\hline Barranquilla & $1 / 68000$ & 1,47 \\
\hline Buenos Aires & $1 / 100000$ & 1,00 \\
\hline Santiago de Chile & $1 / 100000$ & 1,00 \\
\hline Medellín & $3 / 435774$ & 0,69 \\
\hline Iquique & $2 / 427000$ & 0,47 \\
\hline
\end{tabular}

Table 3. Frequencies of se ve (que) in Latin America

Se ve (que) is only absent in 4 out of the 17 Latin American cities under study, which is the case for Bogotá, Tucumán, Guatemala, San José de Costa Rica. Moreover, considering the LatinAmerican areas where se ve (que) does appear, its presence in all three cities of Mexico under study (principally Acapulco, but also Mexico City and Monterrey) stands out, whereas there were hardly any cases of por lo visto for these areas.

If we now turn to the Spanish data, again, data were obtained for all the cities studied. The table below summarizes the distribution of se ve (que):

\begin{tabular}{|l|l|l|}
\hline Dialectal variant & Cases/total words & Nr./100000 words \\
\hline Granada & $4 / 36000$ & 11,11 \\
\hline Castellón & $55 / 575000$ & 9,57 \\
\hline Valencia & $70 / 770000$ & 9,09 \\
\hline Palma de Mallorca & $6 / 120000$ & 5,00 \\
\hline Sevilla & $2 / 40000$ & 5,00 \\
\hline Málaga & $6 / 160000$ & 3,75 \\
\hline Madrid & $7 / 400000$ & 1,75 \\
\hline Las Palmas de Gran Canaria & $1 / 69000$ & 1,45 \\
\hline Alcalá & $2 / 160000$ & 1,25 \\
\hline Galicia & $4 / 410000$ & 0,98 \\
\hline Table
\end{tabular}

Table 4. Frequencies of se ve (que) in Spain

As shown in Table 3, the highest frequencies are obtained for Granada, Castellón, Valencia, Palma de Mallorca and Seville. In other words, these data suggest that, to some extent, there is a higher concentration of se ve (que) in the Catalan-Spanish bilingual area (Valencia, Castellón and Palma de Mallorca), in addition to the areas of Granada and Seville that certainly deserve a more thorough analysis in the future.

To sum up, this comparison of the dialectal differences in the evidential markers se ve (que) and por lo visto has shown that both markers are used much more frequently in the Iberian peninsula. Within this area, there seems to be a concentration of por lo visto in the Andalusian area and of se ve (que) in the Catalan-Spanish bilingual area. In an attempt to explain the low frequencies of these markers in many cities of Latin America, we postulate that this can be explained by the existence of - and subsequent competition with - other evidential markers in these areas that are not generally used in Spain, (dizque, diz que, quizque, etc.). 


\subsection{Diaphasic differences}

In general, the evidential markers are used more frequently in informal conversations than in (semi)formal interviews, where they appear in 7,52 vs. 3,65 cases/100000 words, respectively. Moreover, se ve (que) clearly dominates in both registers. However, considering por lo visto and se ve (que) separately, we see a slight preference for por lo visto in formal registers $(1,35$ formal vs. 1,17 informal), whereas se ve (que) clearly abounds in informal ones $(6,35$ informal vs. 2,3 formal). The following table summarizes the distribution between por lo visto and se ve (que) according to register:

\begin{tabular}{|l|c|c|c|c|c|c|}
\hline & \multicolumn{2}{|c|}{$\begin{array}{c}\text { (semi)Formal } \\
\text { Interviews }\end{array}$} & \multicolumn{2}{c|}{$\begin{array}{c}\text { Informal } \\
\text { Conversations }\end{array}$} & \multicolumn{2}{c|}{ Total } \\
\cline { 2 - 7 } & $\#$ & $\begin{array}{c}\text { Nr./100 000 } \\
\text { words }\end{array}$ & $\#$ & $\begin{array}{c}\text { Nr./100 000 } \\
\text { words }\end{array}$ & $\#$ & $\begin{array}{c}\text { Nr. /100 000 } \\
\text { palabras }\end{array}$ \\
\hline $\begin{array}{l}\text { por } \\
\text { visto }\end{array}$ & $73 / 5384946$ & 1,35 & $17 / 1449000$ & 1,17 & $90 / 6833946$ & $\mathbf{1 , 3 1}$ \\
\hline $\begin{array}{l}\text { se ve } \\
(\text { que })\end{array}$ & $124 / 5384946$ & 2,3 & $92 / 1449000$ & 6,35 & $216 / 6833946$ & $\mathbf{3 , 1 6}$ \\
\hline Total & $197 / 5384946$ & $\mathbf{3 , 6 5}$ & $109 / 1449000$ & $\mathbf{7 , 5 2}$ & $306 / 6833946$ & $\mathbf{4 , 4 7}$ \\
\hline
\end{tabular}

Table 5. Diaphasic distribution of se ve que and por lo visto

This register preference of each marker is attested most clearly in the cities for which we obtained corpora from both genres: in some areas there is a definite primacy of por lo visto in interviews (and formal register) and of se ve (que) in conversation (informal speech). A clear example is the case of Buenos Aires:

$\begin{array}{llll} & \text { (semi)formal interviews } & & \text { informal conversations } \\ \text { se ve (que): } & 0 / 100000 & \text { vs. } & \mathbf{1} / 100000 \\ \text { por lo visto: } & \mathbf{1 , 7 9 / 1 0 0 0 0 0} & \text { vs. } & 0 / 100000\end{array}$

Although these first quantitative data suggest a slight preference for each marker to appear in different registers, and also suggest a certain correlation between the use of por lo visto and se ve (que) in formal vs. informal registers respectively, bear in mind that the results obtained here and the possible generalizations drawn from them only apply to the two genres studies here, namely (semi)formal sociolinguistic interviews and colloquial conversations. Other discursive genres could reveal different results, depending on the need that each genre has to express evidentiality. In that respect, for example, it would be interesting to compare these data with informative news broadcasts, where evidentiality is considered to be omnipresent.

\subsection{Differences according to the mode of knowledge expressed}

Finally, after studying in more detail the differences according to the mode of knowledge expressed, it turns out that both por lo visto and se ve (que) are able to express inferential and reportative modes. However, they differ considerably with respect to their distribution: por lo visto displays a higher frequency of reportative evidentiality $(66,7 \%)$, as illustrated in example (10) above, whereas se ve (que) prefers inferential evidentiality (74\%), exemplified in sentence (11) in Section 4. 


\begin{tabular}{|l|l|l|l|l|l|l|}
\hline \multicolumn{1}{l|}{} & $\#$ & $\%$ & $\#$ & $\%$ & $\#$ & $\%$ \\
\hline por lo visto & 30 & 33,3 & 60 & $\mathbf{6 6 , 7}$ & 0 & 0 \\
\hline se ve (que) & 160 & $\mathbf{7 4}$ & 47 & 22,2 & 8 & 3,8 \\
\hline
\end{tabular}

Table 6. modes of knowledge expressed

As shown in Table 6, there was also a small portion of se ve (que) expressing visual (indirect) evidentiality. As explained above (see example 8), in these cases, se ve que is not an evidential particle, precisely for maintaining its compositional, physical perception sense.

\section{Conclusion}

To conclude, the main objective of this study was to present a contrastive, corpus-based analysis of the evidential markers por lo visto and se ve (que) along two axes of variation, namely dialectal and diaphasic. More specifically, three research questions were formulated:

1. Do we observe dialectal differences in terms of frequency of use of both markers? Are there any areas where one specific form dominates? And in that case, what could be the underlying explanation for these diverging dialectal patterns?

2. Are there any diaphasic differences in the use of both markers? That is to say, do we observe any differences according to register (formal vs. informal speech)?

3. From a qualitative point of view, to what extent do their evidential meaning differ according to the mode of knowledge expressed (reportative, inferential, visual)?

With respect to the dialectal variation, this study has shown that although both evidential markers are present in Spain and Latin America, they tend to be more commonly used in Spain. In general, se ve (que) is much more frequent than por lo visto. In an attempt to explain the low frequency of these markers in Latin America, we hypothesize that this can be explained by the existence of - and competition with - other evidential markers in these areas that are not generally used in Spain (dizque, diz que, quizque, etc.). Therefore, it would be interesting for a future project to broaden the scope and compare the dialectal behavior of por lo visto and se ve (que) with other evidential markers that have not been taken into account in this study (al parecer, según parece, según dicen, dizque, etc.).

Related to the diaphasic variation, we noted a tendency to use se ve (que) in informal registers and por lo visto in formal ones. Of course, this tendency should also be verified in future studies by taking into account other genres, such as news broadcasts or parliamentary speeches.

Finally, with respect to the modes of knowledge expressed, por lo visto seems to express preferably reportative evidentiality, whereas se ve (que) more often expresses inferential evidentiality.

\section{References}

AIKHENVALD, A. (2004): Evidentiality. Oxford: University Press.

ALBELDA, M. (ed.) (2015): Evidentiality in non-evidential languages: Are there evidentials in Spanish? Journal or pragmatics 85. 
ALBELDA, M. (2016): "La expresión de la evidencialidad en la construcción se ve (que)", Spanish in Context 13.2, p. 237-262.

ALBELDA, M. (in press): “¿Atenuación del compromiso del hablante?: el caso de los evidenciales por lo visto y se ve que", Rilce.

ANDERSON, Ll. (1986): "Evidentials, Paths of Change and Mental Maps: Typologically Regular Asymmetries", en Evidentiality: The Linguistic Coding of Epistemolog, ed. por CHAFE, W. \& NICHOLS, J., Berlin: Mouton de Gruyter, p. 273-312.

BERMÚDEZ, F. (2005): Evidencialidad: La codificación lingüística del punto de vista. $\mathrm{PhD}$ Dissertation: Stockholm Universitet.

BIBER, D. \& E. FINEGAN. 1988. Adverbial Stance Types in English. Discourse Processes 11, 1-34.

BOYE, K. (2010): "Evidence for what? Evidentiality and scope", STUF Language Typology and Universals 63/4, p. 290-307.

BRIZ, A. PORTOLÉS, J. y PONS, S. (eds): Diccionario de partículas discursivas del español. Accesible en línea: www.dpde.es.

CHAFE, W. \& J. NICHOLS (eds.). 1986. Evidentiality: The Linguistic Coding of Epistemology. Norwood: Ablex.

CORNILLIE, B. (2016): "Las lecturas evidenciales de los verbos (semi)auxiliares en español", in GONZÁLEZ, R., IZQUIERDO, D. \& LOUREDA, O. (eds.): La evidencialidad en español: teoría y descripción, p. 227-250.

CORNILLIE, B. \& D. IZQUIERDO (eds.). (2018). Gramática, semántica y pragmática de la evidencialidad. Pamplona: EUNSA.

CORNILLIE, B. \& GRAS, P. (2015): "On the interactional dimension of evidentials: The case of the Spanish evidential discourse markers”, Discourse Studies 17/2: 141-161.

CUENCA, M. \& MARÍN, M. (2000). Verbos de percepción gramaticalizados como conectores. Análisis contrastivo español-catalán. Revista Española de Lingüística aplicada, 215-237.

DE LA MORA, J. \& R. MALDONADO (2015): "Dizque: Epistemics blurring evidentials in Mexican Spanish", Journal of Pragmatics 85, p. 168-180.

DE SAEGER, B. 2006. Evidencialidad y modalidad epistémica en los verbos de actitud proposicional en español. Interlingüística 17, 268-277.

DIEWALD, G. \& E. SMIRNOVA (2010): "Introduction", en Eds. Gabrielle Diewald y Elena Smirnova (eds.): Evidentiality in European Languages: the lexical-grammatical distinction, p. 1-14.

ENGHELS, R. (2007): Les modalités de perception visuelle et auditive. Différences conceptuelles et répercussions sémantico-syntaxiques en espagnol et en français, Tübingen: Niemeyer.

ESCANDELL, V. 2010. Futuro y evidencialidad. Anuario de Lingüística Hispánica 26: 9-34.

ESTELLÉS, M. 2015. Expressing evidentiality through prosody? Special Issue en Journal of Pragmatics 85, 138-154.

ESTELLÉS, M. (in press): "What Genres Tell Us about Evidentials and vice versa: A Study of al parecer in Spanish Parliamentary Debates", Pragmatics \& Society.

FERNÁNDEZ JAÉN, J. (2012): Semántica diacrónica cognitiva de los verbos de percepción física del español. $\mathrm{PhD}$ Dissertation. Universidad de Alicante.

FRAWLEY, W. (1992): Linguistic Semantics, Hillsdale, NJ: Lawrence Erlbaum.

FUENTES RODRÍGUEZ, C. (2009): Diccionario de conectores y operadores del español actual, Madrid: Arco/Libros.

GONZÁLEZ CONDOM, M. (ed.), 2015. Evidential and epistemic strategies in discourse. A crosslinguistic perspective. Discourse Stud. 17(2).

GONZÁLEZ MELÓN, E. \& H. HANEGREEFS (2011). Efectos discursivos de los marcadores mira y a ver en contextos argumentativos orales: divergencia vs. convergencia comunicativa. Actas del 
XXXIX simposio internacional de la Sociedad Española de Lingüística. Santiago de Compostela: Universidad de Santiago de Compostela. [Online]

https://lirias.kuleuven.be/bitstream/123456789/387552/1/GonzalezMelon\%26Hanegreefs.pdf

GONZÁLEZ RAMOS, E. (2016): "Por lo visto y al parecer: evidencialidad y restricción del compromiso con la verdad de un contenido enunciado", in GONZÁLEZ, R., IZQUIERDO , D. \& LOUREDA, O. (eds.): La evidencialidad en español. Teoría y descripción, Madrid: Iberoamericana, p. 129-152.

GONZÁLEZ, R., D. IZQUIERDO \& Ó. LOUREDA (eds.). 2016. La evidencialidad en español. Teoría y descripción. Madrid, Iberoamericana.

HANEGREEFS, H. (2008): Los verbos de percepción visual. Un análisis de corpus en un marco cognitivo, Leuven: KULeuven dissertation.

HASSLER, G. (2010): "Epistemic modality and evidentiality and their determination on a deictic basis: the case of Romance languages", en DIEWALD, G. y SMIRNOVA, E. (Eds). Evidentiality in European Languages: the lexical-grammatical distinction, p. 223-248.

HUGO, E. (2011): Las formas de segunda persona singular como estrategias evidenciales. RLA 49(1): 143-167.

IBARRETXE-ANTUÑANO, I. (1999): Polysemy and metaphor in perception verbs: a cross-linguistic study. Edinburgh: Universidad de Edinburgh.

IZQUIERDO, D. (2016): Alcance y límites de la evidencialidad. Aspectos teóricos y propuesta de análisis aplicada a un conjunto de adverbios evidencialoides del español. $\mathrm{PhD}$ Dissertation. Pamplona: Universidad de Navarra.

JANSEGERS, M. \& S. Th. GRIES (2017): "Towards a dynamic behavioral profile: A diachronic study of polysemous sentir in Spanish", Corpus Linguistics and Linguistic Theory, p. 1-42.

KOTWICA, D. (2015): "Al parecer evidencial atenuante. ¿Y reforzador?”, in Eds. ÁLVAREZ, C., GARRIDO, B. \& GONZÁLEZ, M. (eds.): Jóvenes aportaciones a la investigación lingüística, Sevilla: Alfar, p. 481-494.

KOTWICA, D. (2016): Evolución del género artículo científico en español (1799-1920) a la luz de la expresión de la evidencialidad. Tesis doctoral. Valencia: Universitat de València.

KOTWICA, D. (2017) "From Seeing to Reporting: Grammaticalization of Evidentiality in Spanish Constructions with ver ('to see')". In Marín-Arrese, Juana I. et al. (eds.) Evidentiality and Modality in European Languages. Discourse-pragmatic perspectives, Peter Lang, Bern pp 87-109.

MARCOS, M. (2016): "Subjetividad e intersubjetividad en los marcadores evidenciales formados por el verbo de percepción visual ver en español", en GONZÁLEZ, R., IZQUIERDO, D. \& LOUREDA, O. (eds.): La evidencialidad en español. Teoría y descripción, Madrid: Iberoamericana, p. 153-178.

MATLOCK, T. (1989): "Metaphor and the grammaticalization of evidentials", Proceedings of the Annual Meeting of the Berkeley Linguistic Society 15, p. 215-225.

MIGLIO, V. (2010): "Online databases and language change: the case of Spanish dizque", Language and Computers 71/1, p. 7-28.

PONS, S. (1998). Oye y mira o los límites de la conexión. In María Antonia Martín \& Estrella Montolío (eds.), Marcadores discursivos: teoría y práctica 213-228. Madrid: Arco Libros.

RUIZ GURILLO, L. (2005): "Las locuciones marcadoras del español: análisis y aplicaciones", en ALMELA, R., TRIVES, E. y WOTJAK, G. (eds.): Fraseología contrastiva, Murcia: Universidad de Murcia, p. 241-257.

SANTOS, L. (2003): Diccionario de partículas, Salamanca: Luso-Española de Ediciones.

SCHWENTER, S. 1999. "Evidentiality in Spanish morphosyntax: a reanalysis of (de)queísmo". En: Estudios de la variación sintáctica, ed. por M. José Serrano, 65-87, Iberoamericana, Madrid. 
SQUARTINI, M. (2008): “Lexical vs. grammatical evidentiality in French and Italian”, Linguistics 46/5, p. 917-947.

SWEETSER, E. (1990): From Etymology to Pragmatics: Metaphorical and Cultural Aspects of Semantic Structure, Cambridge University Press.

TANGHE, S. \& JANSEGERS, M. (2014): "Marcadores del discurso derivados de los verbos de percepción: un análisis comparativo entre el español y el italiano", Revue Romane 49/1, p. 1-31.

TORNER, S. (2016). "Los adverbios evidenciales en español”. En La evidencialidad en español: teoría y descripción, ed. por R. González, D. Izquierdo \& Ó. Loureda, 251-257. Madrid: Vervuert.

TRAUGOTT, E. \& G. TROUSDALE (2013): Constructionalization and Constructional Changes, Oxford University Press.

VAN OLMEN, D. (2010a). Imperatives of visual versus auditory perception as pragmatic markers in English and Dutch. English Text Construction 3, 74-94.

VIBERG, A. (1984). The verbs of perception: a typological study. Linguistics 21, 123-162.

WHITT, R. (2010): Evidentiality and Perception Verbs in English and German, Peter Lang: Berna.

\section{Corpora}

BARROS, P., BARROS, M. J., LÓPEZ, M. P. y MORALES, J. (2012): Cogila: español oral conversacional, Granada: Universidad de Granada.

BLAS , J. L. (coord.) (2010): Corpus sociolingüístico de Castellón de la Plana y su área metropolitana, Castellón: Universitat Jaume I.

BRIZ, A. \& Val.Es.Co. Group (2002): Corpus de conversaciones coloquiales. Madrid: Arco/Libros.

CABEDO, A. \& PONS, S. (online): Corpus Val.Es.Co. 2.0. Accesible en línea: www.valesco.es.

GÓMEZ, J. R. (coord.) (2001-2007): El español hablado de Valencia. Materiales para el estudio sociolingüístico. Vol. I. Nivel sociocultural Alto, Medio, Bajo. Valencia: Universitat de València.

LASARTE, M. de la Cruz, VILLENA, J. A. y ÁVILA, A. M. (2009): El español hablado en Málaga III. Corpus oral para su estudio sociolingüístico. Nivel de estudios alto, Sarriá: Málaga.

MORENO, F., CESTERO, A. M., MOLINA, I. y PAREDES, F. (2002): La lengua hablada en Alcalá de Henares. Corpus PRESEEA-ALCALÁ I: Hablantes de instrucción superior, Alcalá de Henares: Universidad de Alcalá. CD-Rom.

MÉNDEZ, B. (2015): Corpus Oral Juvenil del Español de Mallorca (COJEM), Lingüística en Red, Universidad de Alcalá.

MOYA, J. A. (coord.) (2007): El español hablado en Granada. Corpus oral para su estudio sociolingüístico. I Nivel de estudios alto, Granada: Universidad de Granada.

MYRE, A. (online): Corpus COLAm: Corpus Oral de Lenguaje Adolescente. Accesible online www.colam.org.

PRESEEA (2014-2017): Corpus del Proyecto para el estudio sociolingüístico del español de España y de América, Alcalá de Henares: Universidad de Alcalá. Accesible online: http://preseea.linguas.net. Consulted: March 2017.

SALVADOR, F. (coord.) (2007): El habla culta de granada: Materiales para su estudio, Granada: Universidad de Granada.

SAMPER, J. A. (1998): Macrocorpus de la norma lingüística culta de las principales ciudades del mundo hispánico, Las Palmas: Universidad.

VV.AA. (online): Corpus Ameresco. Proyecto Es.VaG.Atenuacion. Accesible en línea: http://esvaratenuacion.es.

VV.AA. (online): ESLORA: Corpus para el estudio del español oral. Accesible en línea: http://galvan.usc.es/eslora, versión 1.0 November 2016. 